L. B. Nielsen · H. B. Mortensen · F. Chiarelli • R. Holl •

P. Swift - C. de Beaufort - F. Pociot - P. Hougaard •

S. Gammeltoft • M. Knip • L. Hansen •

Hvidøre Study Group

\title{
Impact of IDDM2 on disease pathogenesis and progression in children with newly diagnosed type 1 diabetes: reduced insulin antibody titres and preserved beta cell function
}

Received: 24 May 2005 / Accepted: 23 August 2005 / Published online: 23 November 2005

(C) Springer-Verlag 2005

\begin{abstract}
Aims/hypothesis: The insulin-dependent diabetes mellitus 2 gene (IDDM2) is a type 1 diabetes susceptibility locus contributed to by the variable number of tandem repeats (VNTR) upstream of the insulin gene $(I N S)$. We investigated the association between INS VNTR class III alleles $(-23 H p h I \mathrm{~A} / \mathrm{T})$ and both insulin antibody presentation and residual beta cell function during the first year after diagnosis in 257 children with type 1 diabetes. Materials and methods: To estimate C-peptide levels and autoantibody presentation, patients underwent a mealstimulated C-peptide test 1, 6, and 12 months after diagnosis. The insulin $-23 H p h I A / T$ variant was used as a marker of class III alleles and genotyped by PCR-RFLP. Results: The insulin antibody titres at 1 and 6 months were significantly lower in the class III/III and class I/III genotype groups than in the class I/I genotype group $(p=$ $0.01)$. Class III alleles were also associated with residual beta cell function 12 months after diagnosis and independently of age, sex, BMI, insulin antibody titres, and
\end{abstract}

\footnotetext{
L. B. Nielsen $(\bowtie) \cdot$ H. B. Mortensen

Department of Paediatrics, Glostrup University Hospital,

Ndr. Ringvej 57,DK-2600, Glostrup, Denmark

e-mail: lbn@dcb-glostrup.dk

Tel.: +45-432-32475

Fax: $+45-432-33929$

F. Chiarelli

Department of Paediatrics, University of Chieti,

Chieti, Italy

R. Holl

Department of Mathematics, The University of Ulm,

Ulm, Germany

P. Swift

Department of Paediatrics,

Leicester Royal Infirmary Children's Hospital,

Leicester, UK

C. de Beaufort

Paediatric Clinic,

Luxemburg, Luxemburg
}

HLA-risk genotype group ( $p=0.03$ ). The $\mathrm{C}$-peptide level was twice as high among class III/III genotypes as in class I/I and class I/III genotypes (319 vs 131 and $166 \mathrm{pmol} / \mathrm{l}$, $p=0.01)$. Furthermore, the class III/III genotype had a $1.1 \%$ reduction in $\mathrm{HbA}_{1} \mathrm{c}$ after adjustment for insulin dose $(p=0.04)$. Conclusions/interpretation: These findings suggest a direct connection in vivo between INS VNTR class III alleles, a decreased humoral immune response to insulin, and preservation of beta cell function in recentonset type 1 diabetes.

Keywords Beta cell function - IDDM2 .

Insulin antibodies - Type 1 diabetes

Abbreviations GADA: GAD antibodies - IA-2A:

antibodies against insulinoma-associated antigen - ICA: islet cell antibody - VNTR: variable number of tandem repeats

F. Pociot

Steno Diabetes Center,

Gentofte, Denmark

P. Hougaard

Department of Statistics,

University of Southern Denmark,

Odense, Denmark

S. Gammeltoft

Department of Clinical Biochemistry,

Glostrup University Hospital,

Glostrup, Denmark

M. Knip

Hospital for Children and Adolescents,

University of Helsinki,

Helsinki, Finland

L. Hansen

Science and Medicine,

Novo Nordisk A/S,

Bagsværd, Denmark 


\section{Introduction}

Four genetic loci have been confirmed as being involved in the development of type 1 diabetes: HLA class II region (insulin-dependent diabetes mellitus $1[I D D M 1]$ ), cytotoxic T-lymphocyte-associated protein 4 (CTLA4), insulin-dependent diabetes mellitus 2 (IDDM2), which is contributed to by the variable number of tandem repeats (VNTR) region upstream of the insulin gene (INS), and LYP/ PTPN22 [1-4].

The INS VNTR class III alleles were previously described as a dominant trait with relative protection against developing type 1 diabetes. However, recent studies have questioned this observation [5]. It has been suggested that association of the class III alleles with higher thymic insulin mRNA expression and lower titres of insulin autoantibodies are the protective mechanisms behind reduced autoimmunity directed against beta cells [6]. It has also been reported that, in comparison with a class I allele, an INS VNTR class III allele exerts higher transcriptional activity on the insulin gene in vitro [7].

We analysed the effect of INS VNTR class I and III alleles on insulin antibody titres in relation to residual beta cell function during the first 12 months after diagnosis in children with type 1 diabetes.

\section{Subjects and methods}

Subjects This observational study was conducted in 18 centres representing 15 countries in Europe and Japan. Clinical information on demographics and anthropometry, insulin and infusion therapy, hospital admission and severe hypoglycaemia, as well as blood samples for centralised measurement of $\mathrm{HbA}_{1} \mathrm{c}$ and boost-stimulated C-peptide, were collected prospectively. Exclusion criteria were: definitive non-type-1 diabetes (MODY, secondary diabetes etc.), rejection of enrolment into the study by patients or parents, and patients initially treated outside the centres for more than 5 days. Diagnosis was according to the World Health Organization criteria.

The cohort included 144 girls and 131 boys, 84\% of whom were white Caucasians. The age at clinical diagnosis was $9.1 \pm 3.7$ years $(\operatorname{mean} \pm \mathrm{SD})$, BMI was $16.5 \pm 3.2 \mathrm{~kg} / \mathrm{m}^{2}$, and $\mathrm{HbA}_{1} \mathrm{c}$ was $11.2 \pm 2.1 \%$. Diabetic ketoacidosis was present in $20.7 \%$ of the cases at the time of diagnosis $\left(\mathrm{HCO}_{3}<15 \mathrm{mmol} / 1\right.$ and/or $\left.\mathrm{pH}<7.30\right)$.

The study was performed according to the criteria of the Helsinki II Declaration and was approved by the local ethic committee in each centre. All patients and their parents or guardians gave informed consent.

Genotyping The -23HphIA/T polymorphism (rs689) was used as a marker for the VNTR region as described earlier [8].

Typing of the HLA-class II $D R B 1$ locus was performed by direct sequencing of exon 2 of $D R B 1$ according to the Immuno Histocompatibility Working Group [9].
Clinical biochemistry $\mathrm{HbA}_{1} \mathrm{c}$ and C-peptide were analysed centrally by ion-exchange high-performance liquid chromatography and a fluoroimmunometric assay (AutoDELFIA C-peptide; PerkinElmer Life Sciences Wallac, Turku, Finland) respectively.

Beta cell function At 1, 6, and 12 months after diagnosis a total of the 257 of the 275 patients underwent a Booststimulated C-peptide test. The test was performed in the morning after at least $8 \mathrm{~h}$ fasting, the morning insulin dose was given after the test. In agreement with the Diabetes Control and Complications Trial protocol, capillary glucose was measured at time 0 and venous C-peptide and glucose at 90 min after ingestion of Boost.

Antibodies Insulin antibodies were measured by a modified version of a method that has been previously described [10]. The cut-off limit for positivity was 1.56 relative units, representing the 99th percentile in a group of 371 non-diabetic subjects.

Statistical methods The two main hypothesis evaluated were that the INS VNTR class III alleles are associated (1) with reduced insulin antibody titres, and (2) with preserved beta cell function. Most evaluations were based on normal distribution, but C-peptide was considered on the logarithmic scale. The distribution of insulin antibody titres was so skewed that non-parametric tests (KruskalWallis) were used to evaluate the effect of the INS VNTR genotype on insulin antibody levels. C-peptide and $\mathrm{HbA}_{1} \mathrm{C}$ were analysed by means of multiple regression, using age, sex, BMI, HLA-risk group, ketoacidosis at onset, INS VNTR genotype, and insulin antibody levels (four groups: negative, low, medium, high) as explanatory factors in a compound symmetric repeated measurement model. A $p$ value of 0.05 or less was considered significant.

\section{Results}

Antibody-negative patients Among the patients, 22 tested negative for GAD antibodies (GADA), islet cell antibodies (ICA), and antibodies against insulinoma-associated antigen (IA-2A) throughout the study period. As these patients might represent an idiopathic and non-autoimmune type of diabetes, they were excluded from the analysis of the effect of INS VNTR on insulin antibodies, C-peptide and insulin-dose-adjusted $\mathrm{HbA}_{1} \mathrm{c}$.

INS VNTR and allele frequency The INS VNTR class I allele frequency was $85.2 \%$ and the frequencies of class I/I $(73.5 \%)$, class I/III $(23.3 \%)$, and class III/III (3.1\%) genotypes were in Hardy-Weinberg equilibrium. Patients with the class III/III genotype were equally distributed between the sexes, slightly older, and had a modestly and non-significantly higher BMI ( $p=0.59$ adjusted for age) compared to the other two genotype groups. All patients with the class III/III genotype were positive for at least one 
Fig. 1 Insulin antibody titres (medians) after 1 and 6 months were lower in the combined class III/III and III/I genotype groups $(* p=0.01$ and $p=0.01$ dominant model) and in the INS VNTR class III/III genotype group ( $* p=0.03$ and $p=0.02$ ) compared to the class I/I genotype group

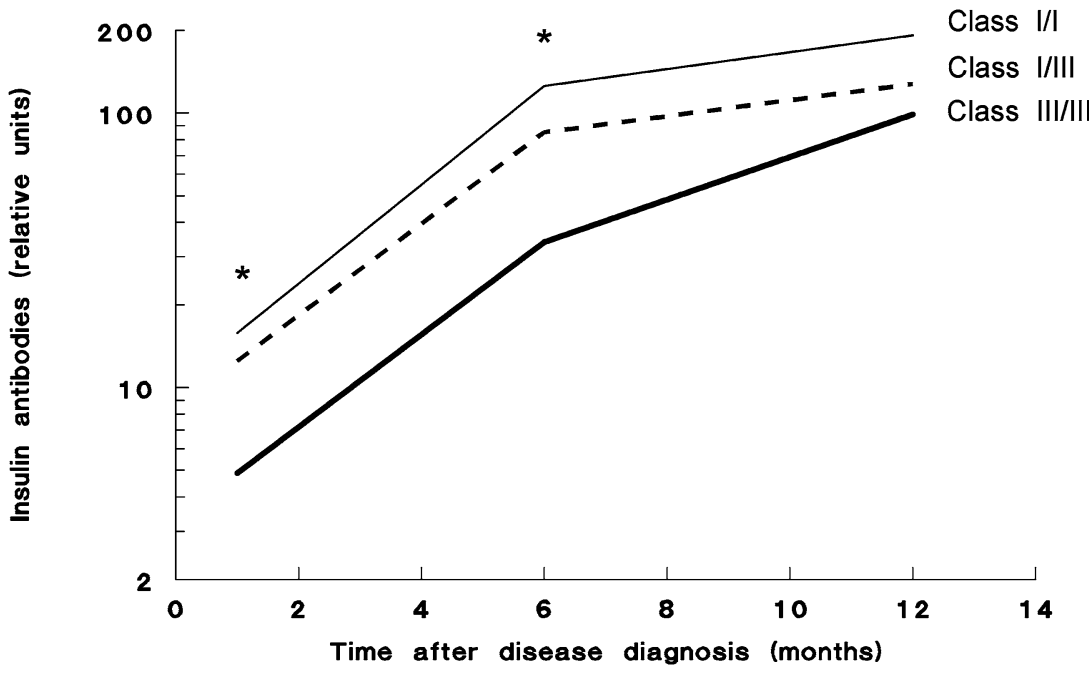

autoantibody (ICA, IA-2A, GADA) and were distributed equally among the three HLA-risk groups.

INS VNTR and insulin antibodies In a dominant model the INS VNTR class III alleles (class I/III and class III/III vs class I/I) were associated with lower titres of insulin antibodies at 1 and 6 months $(p=0.014$ and $p=0.011$, Fig. 1), and the INS VNTR class III/III genotype alone was associated with significantly lower insulin antibodies than the class I/I and class I/III genotypes at 1 month and 6 months after diagnosis ( $p=0.03$ and $p=0.02$, Fig. 1 ). At 12 months, however, the differences were no longer significant $(p=0.09)$.

INS VNTR and residual beta cell function Multiple linear regression showed that the INS VNTR geno- types after 12 months of clinical disease were significantly associated with residual beta cell function $(p=0.03)$, and with C-peptide levels (geometric means) that were twice as high in the class III/III group (319 pmol/l) as in the class I/I and class I/III groups respectively (131 and $166 \mathrm{pmol} / \mathrm{l}, p=0.01$, Fig. 2 ).
This apparent association of the INS VNTR genotypes with sex, BMI, corresponding insulin antibody titres, and HLArisk genotype group when these were included in our compound symmetric model.

INS VNTR and glycaemic control The preservation of beta cell function in the class III/III genotype subjects was associated with better glycaemic control than in the class I/I and class I/III genotypes, with an average reduction of insulin-dose-adjusted $\mathrm{HbA}_{1} \mathrm{c}$ of $1.1 \%(p=0.04)$ during the first year of clinical disease (data not shown).

\section{Discussion}

In the present study we investigated the impact of the welldescribed susceptibility gene IDDM2 on disease pathogenesis and disease progression by examining the humoral immune response to insulin and corresponding residual higher residual beta cell function was independent of age,
Fig. 2 C-peptide levels (geometric means) were higher $(p=0.01)$ in the class III/III group than in the class I/I and class III/I groups during the first year of clinical disease. This also applied when accounting for age at diagnosis, sex, BMI, ketoacidosis at diagnosis, and HLA class II risk groups in a compound symmetric repeated measurement model. Error bars represent $1 \mathrm{SE}$

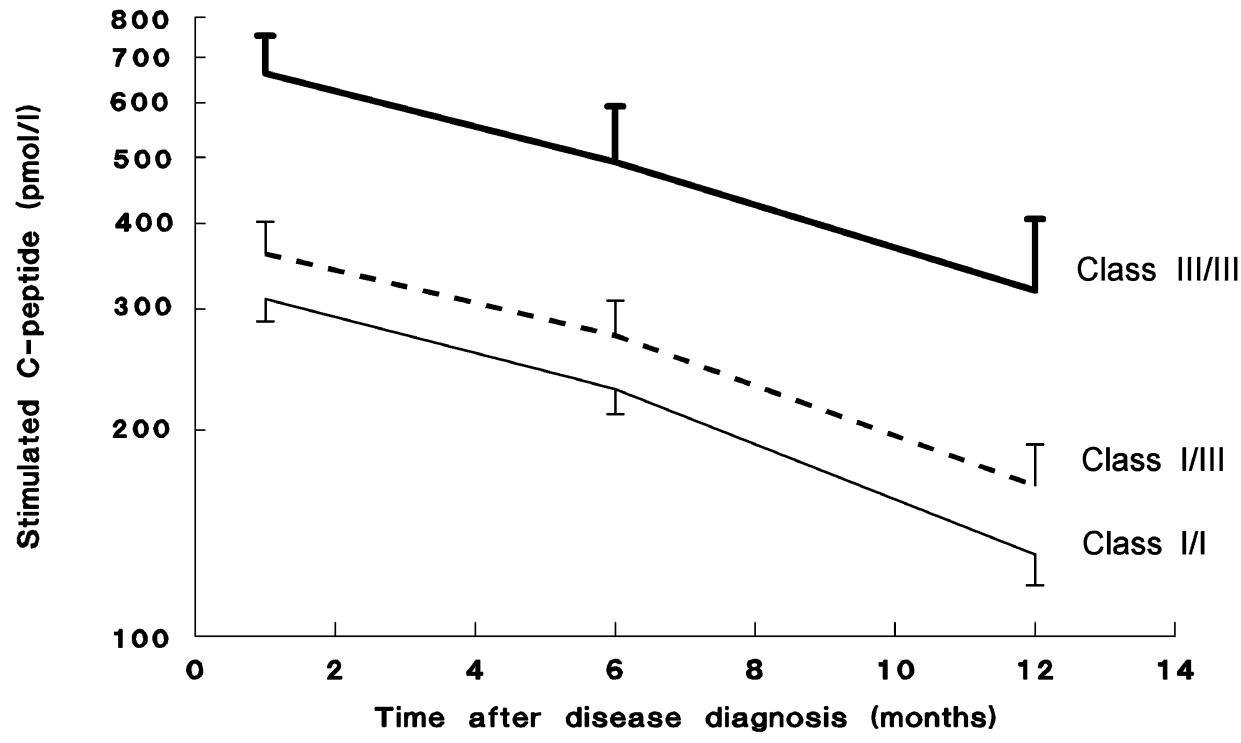


beta cell function during the first 12 months after diagnosis in 257 children with type 1 diabetes.

We found that insulin antibodies were lower in both the class I/III and class III/III genotypes than in the class I/I genotype, and confirmed previous findings $[11,12]$ that carriers of class III alleles inherited a higher tolerance towards endogenous insulin, thus possibly relieving the immunological attack on the beta cells. We also found that class III alleles are associated with higher residual beta cell function and that this putative beta-cell-protective effect of class III alleles seemed to be most evident in the class III/III genotype group who, although only eight patients, also seemed to benefit from a clinically evident improvement in glycaemic control $\left(1.1 \%\right.$ in insulin-dose-adjusted $\mathrm{HbA}_{1} \mathrm{c}$, $p=0.04)$. The class III effect could not be explained by the association of class III alleles with lower titres of insulin antibodies, since inclusion of insulin antibody levels in the C-peptide analysis did not alter the association between preserved beta cell function and the class III/III genotype. In addition, we did not detect any influence of HLA-risk groups on the association between class III alleles and insulin antibodies or beta cell function.

Our data, therefore, suggest that the relative protective effects of class III alleles are caused by both a reduced insulin-directed immune autoreactivity and a possible direct beta-cell-specific effect. However, based on estimations of residual beta cell function, we were not able to determine whether the protective effect of class III alleles was inherited as a dominant, recessive or additive trait $(p=0.08)$. This observation seems to be consistent with most recent genetic studies of the IDDM2 locus [5].

Although it remains controversial, a direct effect of class III alleles on beta cells has previously been demonstrated in non-diabetic infants [13], adult patients with type 1 diabetes onset after 35 years of age [14] and obese nondiabetic women [15], while others have failed to show such an association [16].

The size of our present study group has clear limitations, but it is tempting to speculate that in type 1 diabetes, class III alleles have a synergistic effect on immune-directed insulin autoreactivity and on preservation of beta cell function, and that this synergy explains why the INS VNTR is only associated with type 1 diabetes, in contrast to the pathogenically less disease-specific HLA, CTLA4, and $L Y P / P T P N 22$ loci, which are also associated with other types of autoimmune diseases.

Acknowledgements We thank Novo Nordisk for support throughout this study, with special thanks to Lene Kaa Meier and Stanislav Smirnov. We are also grateful to the technicians Oda Troest at the department of Clinical Biochemistry, Glostrup University Hospital and Britta Drangsfeldt and Susanne Kjelberg at Steno Diabetes Centre for their assistance.

\section{References}

1. Nerup J, Platz P, Andersen OO et al (1974) HL-A antigens and diabetes mellitus. Lancet 12:864-866

2. Bell GI, Horita S, Karam JH (1984) A polymorphic locus near the human insulin gene is associated with insulin-dependent diabetes mellitus. Diabetes 33:176-183

3. Ueda H, Howson JM, Esposito L et al (2003) Association of the T-cell regulatory gene CTLA4 with susceptibility to autoimmune disease. Nature 29:506-511

4. Bottini N, Musumeci L, Alonso A et al (2004) A functional variant of lymphoid tyrosine phosphatase is associated with type I diabetes. Nat Genet 36:337-338

5. Barratt BJ, Payne F, Lowe CE et al (2004) Remapping the insulin gene/IDDM2 locus in type 1 diabetes. Diabetes 53:1884-1889

6. Vafiadis P, Bennett ST, Todd JA et al (1997) Insulin expression in human thymus is modulated by INS VNTR alleles at the IDDM2 locus. Nat Genet 15:289-292

7. Kennedy GC, German MS, Rutter WJ (1995) The minisatellite in the diabetes susceptibility locus IDDM2 regulates insulin transcription. Nat Genet 9:293-298

8. Huxtable SJ, Saker PJ, Haddad L et al (2000). Analysis of parent-offspring trios provides evidence for linkage and association between the insulin gene and type 2 diabetes mediated exclusively through paternally transmitted class III variable number tandem repeat alleles. Diabetes 49:126-130

9. Genomic analysis of the human MHC. DNA based typing for HLA alleles and linked polymorphisms. In: MGJ Tilanus (ed) IHWG Technical Manual. International Histocompatibility Working Group. Available at http://www.ihwg.org/shared/tm2. htm

10. Williams AJ, Bingley PJ, Bonifacio E, Palmer JP, Gale EA (1997) A novel micro-assay for insulin autoantibodies. J Autoimmun 10:473-478

11. Graham J, Hagopian WA, Kockum I et al (2002) Diabetes Incidence in Sweden Study Group; Swedish Childhood Diabetes Study Group. Genetic effects on age-dependent onset and islet cell autoantibody markers in type 1 diabetes. Diabetes 51:1346-1355

12. Hermann R, Laine A-P, Veijola R et al (2005) The effect of HLA class II, insulin and CTLA4 gene regions on development of humoral beta-cell autoimmunity. Diabetologia 48:17661775

13. Bazaes RA, Petry CJ, Ong KK et al (2003) Insulin gene VNTR genotype is associated with insulin sensitivity and secretion in infancy. Clin Endocrinol (Oxf) 59:599-603

14. Matejkova-Behanova M, Vankova M, Hill M et al (2004) Polymorphism of INS VNTR is associated with glutamic acid decarboxylase antibodies and postprandial C-peptide in patients with onset of diabetes after 35 years of age. Physiol Res 53:187-190

15. Weaver JU, Kopelman PG, Hitman GA (1992) Central obesity and hyperinsulinaemia in women are associated with polymorphism in the 5 ' flanking region of the human insulin gene. Eur J Clin Invest 22:265-270

16. Ahmed S, Bennett ST, Huxtable SJ et al (1999) INS VNTR allelic variation and dynamic insulin secretion in healthy adult non-diabetic Caucasian subjects. Diabet Med 16:910-917 